\title{
Aquifer Characterization and Groundwater Potential Using Integrated Geoelectric Sounding and Geoinformatics in West Maghagha Area, Minia Governorate, Egypt
}

\author{
Abdulaziz M. Abdulaziz ${ }^{1 *}$, Abdalla M. Faid ${ }^{2}$ \\ ${ }^{1}$ Faculty of Engineering, Cairo University, Giza, Egypt \\ ${ }^{2}$ Water Resources Department, National Authority for Remote Sensing and Space Sciences, El-Nozha El-Gedida, \\ Cairo, Egypt \\ Email: *amabdul@miners.utep.edu
}

How to cite this paper: Abdulaziz, A.M. and Faid, A.M. (2017) Aquifer Characterization and Groundwater Potential Using Integrated Geoelectric Sounding and Geoinformatics in West Maghagha Area, Minia Governorate, Egypt. Open Journal of Geology, 7, 1625-1643.

https://doi.org/10.4236/ojg.2017.711109

Received: September 13, 2017

Accepted: November 24, 2017

Published: November 27, 2017

Copyright $\odot 2017$ by authors and Scientific Research Publishing Inc. This work is licensed under the Creative Commons Attribution International License (CC BY 4.0).

http://creativecommons.org/licenses/by/4.0/

\begin{abstract}
The study area is located in the western extension of the Nile Valley near the boundary with the Western Desert, where the groundwater represents the potential water resource for future land development for both industrial purposes and agricultural reclamation. Historically, geoelectric methods proved prospective and practical in exploring for groundwater resources. In this study, 17 Vertical Electric Sounding (VES) were acquired and processed to reveal the subsurface distribution of the water bearing layers and identify the groundwater potential in West Maghagha area. After routine data analysis and calibration, the preliminary results are interpreted in light of the available geological data and indicated the presence of at least four geoelectric layers with model resistivity values up to $2000 \Omega \cdot \mathrm{m}$. The potential aquifer was encountered down to $\sim 120 \mathrm{~m}$ depth with average thickness of $100 \mathrm{~m}$ and is made of argillaceous fractured carbonates. Despite the overall poor quality of this aquifer, the integrated geoelectric and hydrogeologic information indicated a possible potential occurrence of potable groundwater at the southern and northeastern parts of the study area. To improve understanding of the groundwater systems in the study area, detailed aquifer characterization is discussed through integration of the available geologic data, maps, and the geoelectric sections constructed from the VES.
\end{abstract}

\section{Keywords}

Maghagha, Vertical Electric Sounding, Schlumberger Configuration, Subsurface Characterization, Groundwater Systems 


\section{Introduction}

Due to the enormous overpopulation in Egypt over the past century (11 million in 1907 to $\sim 80$ million in 2010) the available resources in the traditionally inhibited lands of the Nile Valley and Delta has undergone sever deterioration and deficiency. Therefore, the government considered agricultural expansion and urban growth on the desert especially that located at the periphery of traditionally cultivated lands in the Nil Delta and Valley, as an obligation for accommodating the growing population [1]. Typically, water resources represent the fundamental parameter for initiation and sustainability of desert land development for both agricultural such industrial purposes. Therefore, exploring the quantity and quality of such valuable resources has the prime importance for these projects [2] [3] [4]. Over decades, Vertical Electrical Sounding (VES) has not only proved practical in exploring groundwater resources but also useful in investigating hydrological, engineering, and environmental problems [5] [6] [7] [8]. It provides a quick and cost-effective technique to explore subsurface patterns but the success of the method is always dependent to the contrast in electric properties between the targets and hosting environment [9].

After modern improvement in hardware technology and data processing software, resistivity survey represents the most common exploration technique in exploring the subsurface for potential groundwater resources and revealing the layer parameters, true resistivity, and thickness of the near subsurface units $(\sim 200 \mathrm{~m})$. VES involves acquiring apparent resistivity measurements through injecting a direct current (I) into the ground from two current electrodes conventionally called $A-B$ and measuring the resulting potential difference $(\Delta V)$ at two potential electrodes known as M-N (Figure 1). The resulting potential difference is subdivided by the injected current and multiplied by the geometrical factor $(\mathrm{K})$, a function of the spacing between current and potential electrodes. For a geologic medium the apparent resistivity is typically a function of lithologic composition and fluid content [10] and therefore, geoelectric units usually define parastratigraphic units with boundaries that commonly don't coincide with the recorded stratigraphic boundaries [11]. Various resistivity configurations of current and potential electrodes were introduced and discussed in literatures (e.g. [12] [13] [14]). The symmetrical Schlumberger array represents the most widely used configuration in DC resistivity survey [12] that is not only easy to conduct in the field but also provides a reasonable resolution associating reliable depth sensitivity. Traditionally, in a resistivity survey the depth of penetration is usually accepted to be about one-third of the separating distance between the current electrodes [15].

For a geologic medium, the apparent resistivity is calculated as a function of the resistance value and a geometric factor using the modified Ohm's formula (Equation (1)):

$$
\rho=K \frac{\Delta v}{\delta}
$$




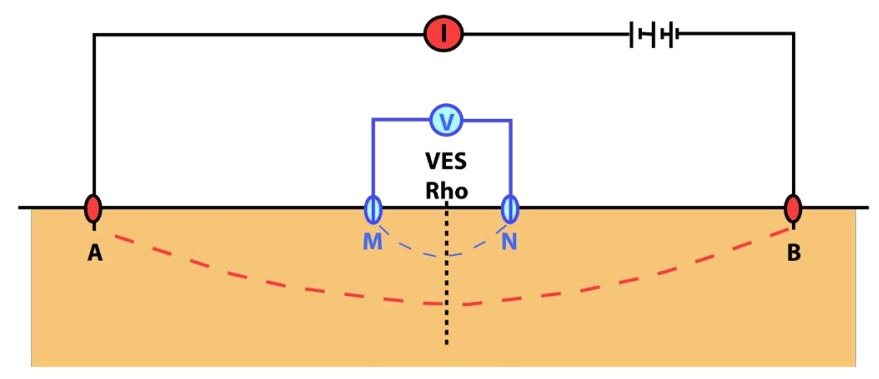

Figure 1. Resistivity configuration of Schlumberger array.

where $\rho$ is the apparent resistivity in $\Omega \cdot \mathrm{m}, K$ is a geometrical factor that accounts for the separating distance of both current and potential electrodes, $v$ is the potential difference in $\mathrm{mV}$, and $\delta$ is the electric current in $\mathrm{mA}$.

Mathematically, the geometric factor of the layers can be calculated using the survey parameters, current electrode spacing, and potential electrode spacing presented in Figure 1, as inputs for Equation (2).

$$
K=\frac{(A B / 2)^{2}-(M N / 2)^{2}}{M N} \Pi
$$

During the VES data acquisition, the mid-point of the survey remains permanent as the separating distance between the electrodes is gradually increased to enable investigating deeper layers while achieving continuous vertical data record (Figure 1). The interpretation of apparent resistivity data is known to be relatively ambiguous, and occasionally obtaining a unique interpretation becomes relatively impossible [10]. However, a good control and wise constraints using borehole data and/or stratigraphic information greatly diminish ambiguity and facilitate interpretation.

The present study aims at characterizing the near-surface geological units to reveal the groundwater potential in West Maghagha using VES integrated to the available geologic information. Such integration helps identifying in details the vertical and horizontal distribution of the subsurface sedimentary units and delineating the important water-bearing horizons. Accordingly, the hydrostratigraphic framework influencing groundwater occurrence in West Maghagha area can be delineated and hence groundwater potential is determined.

\section{Geoinformatics}

\subsection{Location}

The study area constitutes the western boundary of the Nile Valley between Maghagha and Al-Fashn and covers an area of $\sim 41,000 \mathrm{Km}^{2}$ between the latitudes $28^{\circ} 39^{\prime} 00^{\prime \prime}$ and $28^{\circ} 45^{\prime} 12^{\prime \prime} \mathrm{N}$ and the longitudes $30^{\circ} 30^{\prime} 30^{\prime \prime}$ and $30^{\circ} 39^{\prime} 00^{\prime \prime} \mathrm{E}$ (Figure 2). The Nile Valley encompasses the Neogene-sand and gravels that is bounded to the East and West by the Lower Eocene limestone plateau. Being located within arid to semi-arid zone, rainfall is scarce $(<30 \mathrm{~mm} / \mathrm{yr})$ indicating limited local recharge to groundwater system, except for return irrigation water 


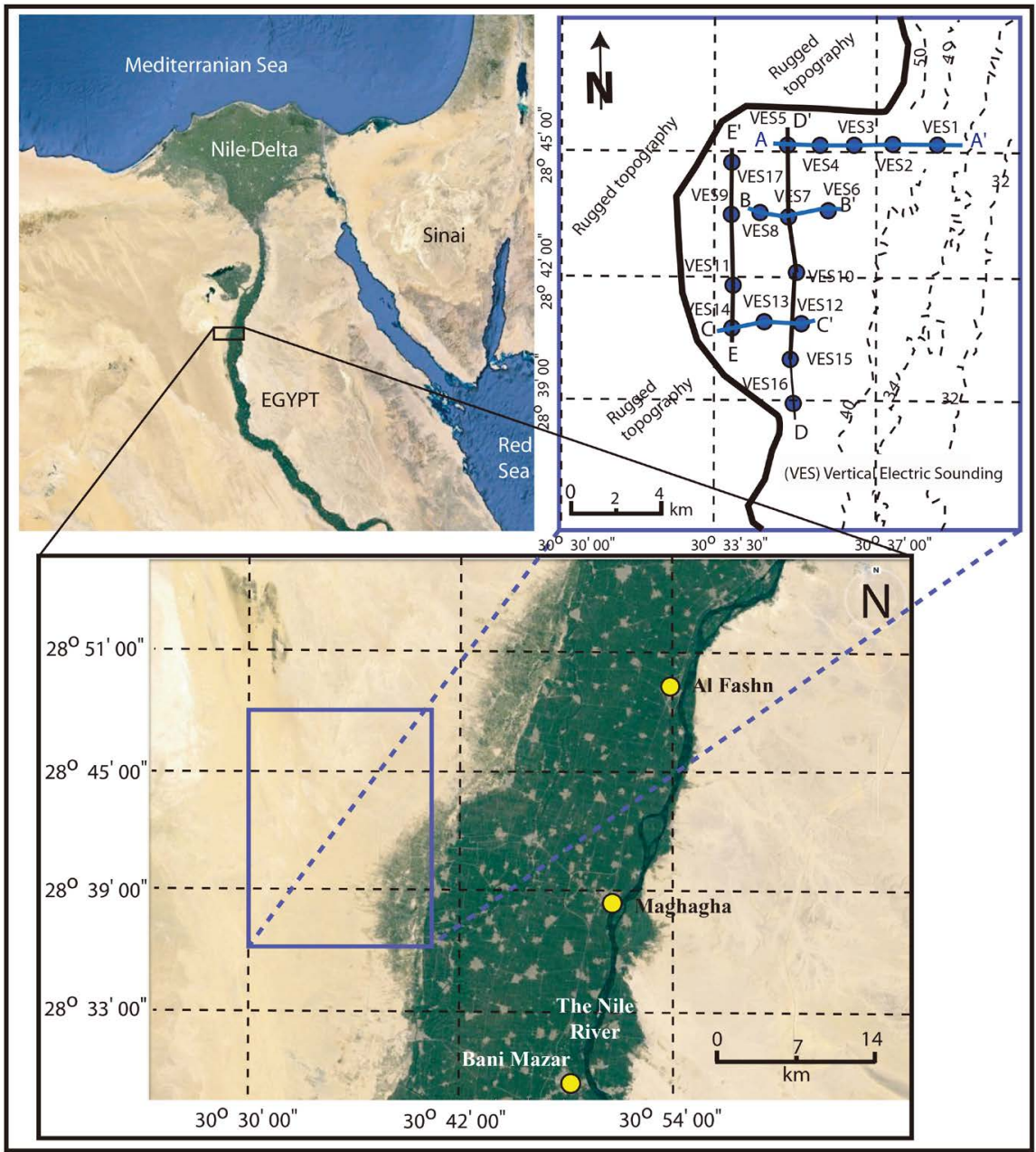

Figure 2. Location map of the VES profiles in West Maghagha area.

and infiltration from surface water courses, with a relatively hot summer (avg. Temp. $31^{\circ} \mathrm{C}$ ) and warm winter (avg. Temp. $16^{\circ} \mathrm{C}$ ).

Topographically, the dominant slope of the study area follows West-East towards the Nile course, with ground level between $60 \mathrm{~m}$ amsl at the Northeast to $210 \mathrm{~m}$ amsl to the West and Northwest. The slope of ground surface is typically shallow at the proximity of the Nile but changes to a relatively steeper slope $(\sim 150 \mathrm{~m} / 10 \mathrm{~km})$ away towards the West. This particularly may explain the present course of the Nile River as being located in the far eastern boundary of the Nile Valley.

\subsection{The Geological Setting}

The Nile Valley is surrounded on both sides by plateaux topped by rocks ranging in age from Precambrian to Eocene. The Nile Valley itself is filled with sediments of Lower Eocene to Recent. Holocene silt and clay occupy young alluvial plains whereas Pleistocene sand and gravels dominate the old alluvial plains bounded on both sides by the Lower Eocene plateau (Figure 3). The Nile Valley is dominantly underlained by Quaternary to Plio-Pleistocene aquifer, but the 


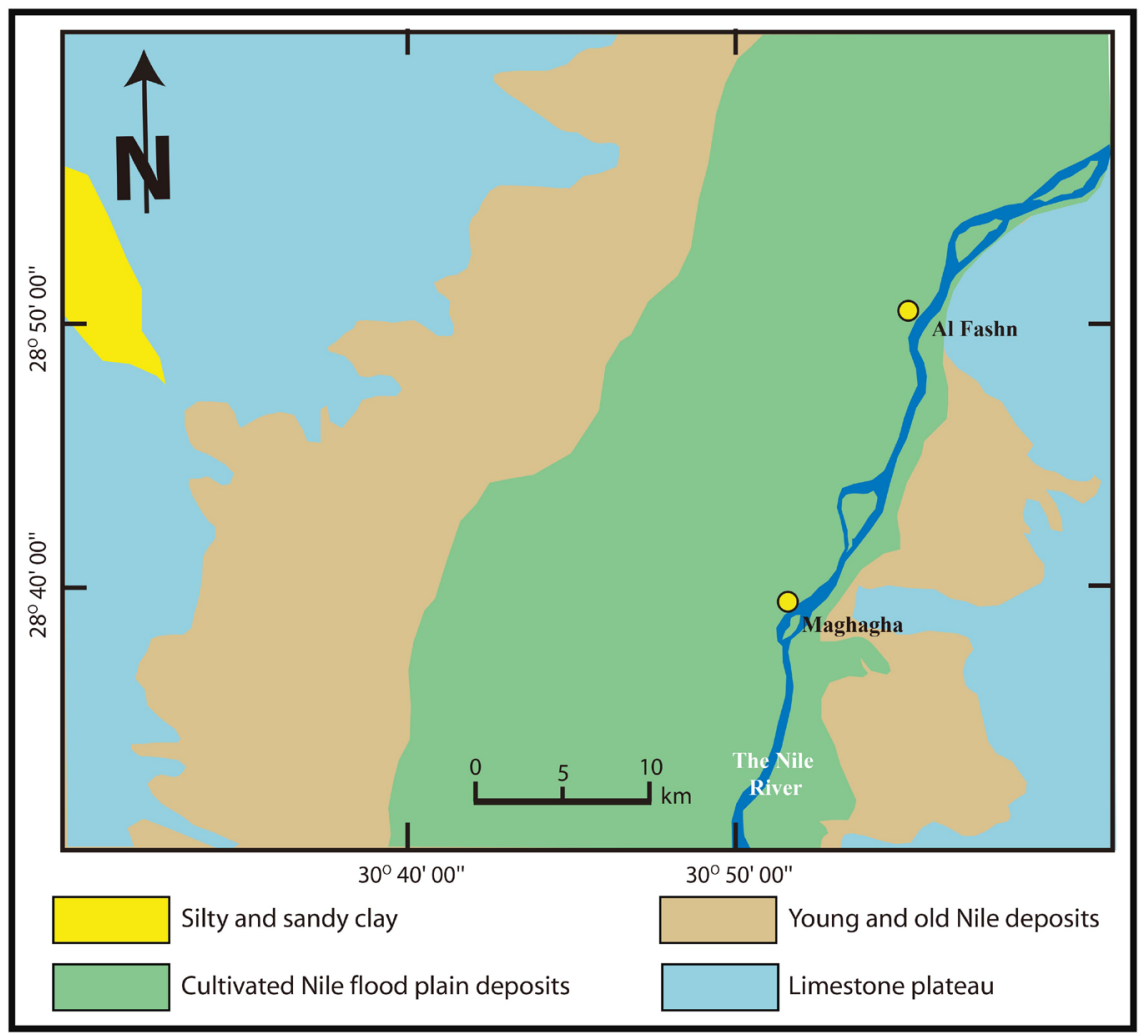

Figure 3. A geologic map of West Maghagha area [18].

Lower Eocene aquifer may acquire groundwater potential. Aquifers represented by the Qena Formation consist of graded sand and gravel in the central portion of the Nile Valley reporting heavy rainfall period. These aquifers are overlain by a silty clay layer of the Pliocene age. Generally, the important lithostratigraphic units in the study area were described in details by Said in [16] and Mansour and Pltilobbo in [17] to include the following units arranged from base to top as the Eocene limestone (Minia Formation and Samalut Formation) and the post Eocene sediments.

The Eocene limestone includes the limestone exposed on both sides of the Nile at the latitude of Minia province that was subdivided into Minia at the base and Samalut at the top and was previously lumped together by Said et al. in [19] and Said in [16] [20] [21] as Middle Eocene Minia Formation. Minia Formation is $35-80 \mathrm{~m}$ thick sediments of snow white limestone that increases in thickness from the West to East and contains faunal assemblages identified by Boukhary and Abdelmalik in [22] as late Early Eocene (Cuisian). Samalut Formation [23] involves 80 - $160 \mathrm{~m}$ of reefal white limestone that locally changes into chalky limestone and stratigraphically separated from the conformably underlying Minia Formation by clay beds [24]. Maghagha Formation overlies Samalut Formation with arenaceous marl and shale at the base and consists of up to $60 \mathrm{~m}$ thick limestone and marl with few intercalations of calcareous sandstone. The Eocene limestone constitutes the target aquifers with a significant groundwater potential 
on both sides of the Nile Valley where the alluvial sand dramatically decreases or totally disappears.

The post Eocene sediments form a series of various heights above the flood plain, covering both sides of the Nile banks at the foot of the scarps. Said in [16] classified these sediments from base to top as; i) Paleonile sediments, ii) PaleoProtonile sediments (Armant and Issawia Formation), iii) Prenile sediments (Qena Formation), iv) Neonile sediments and v) Recent to subrecent alluvial deposits. Each of these classes is assumed to be unique in lithological composition and fluvial cycle [16] but practically categorization is hard to define in subsurface using conventional techniques [24]. Structurally, faults represent the dominant deformational feature within the study area and typically follow two main trends; the most important of them is NW-SE trend, while the other is NE-SW. In addition, folds are also reported as drag type associating faults with fold axes trending in general NW-SE that the main Wadies of the developed drainage system sometimes follow. The axial trends and other structural measurements revealed that these folds were initiated by N $10-20 \mathrm{~W}$ compressional stress [25] [26].

\subsection{Groundwater System}

Previous investigation to the groundwater system of the study area and its environ indicated the presence of four different aquifer systems including; Quaternary, Plio-Pleistocene, Lower Eocene and Nubian Sandstone aquifers. Being accessible and possess economic potential, the Quaternary and Plio-Pleistocene aquifers are typically targeted where they exist. The Quaternary aquifer extends north-south along the central part of the study area following the Nile Valley. The geometry and aquifer characteristics are well determined by the Research Institute for Groundwater using the available well data [27] and geoelectric survey. As shown in the hydrogeological cross section (Figure 4), the Nile alluvium is made of graded sand and gravel with intercalations of clay lenses. The aquifer thickness generally increases from $5 \mathrm{~m}$ at the outer edges of the Nile Valley to 95 $\mathrm{m}$ in the central part (Figure 4). The potentiometric map of the Quaternary aquifer system between 1992 and 2005 (Figure 5) indicates that discharge from the Quaternary aquifer is directed mainly towards the Nile River by transversal flow. Inventorial statistics indicated a continuous decrease in groundwater level of the Quaternary aquifer induced by over-pumping, $166 \times 10^{3} \mathrm{~m}^{3} /$ day in 1984 [28] compared to $191 \times 10^{3} \mathrm{~m}^{3} /$ day in 2000 , to meet the growing demands of water for irrigation and domestic purposes. Based on the presence of the silty-clay layer, the aquifer may change to semi-confined particularly, in the central part of the Nile Valley at the investigated area. However, the aquifer becomes phreatic at the boundary of the Nile Valley [29].

The Plio-Pleistocene aquifer is exposed along the foot slopes of the Eocene limestone on both sides of the Nile Valley (Figure 3 and Figure 4) and extends underneath the Quaternary aquifer in the central part of the Valley. It is mainly made of sand, clay and gravel with a thin cap of a travertine bed. The aquifer 


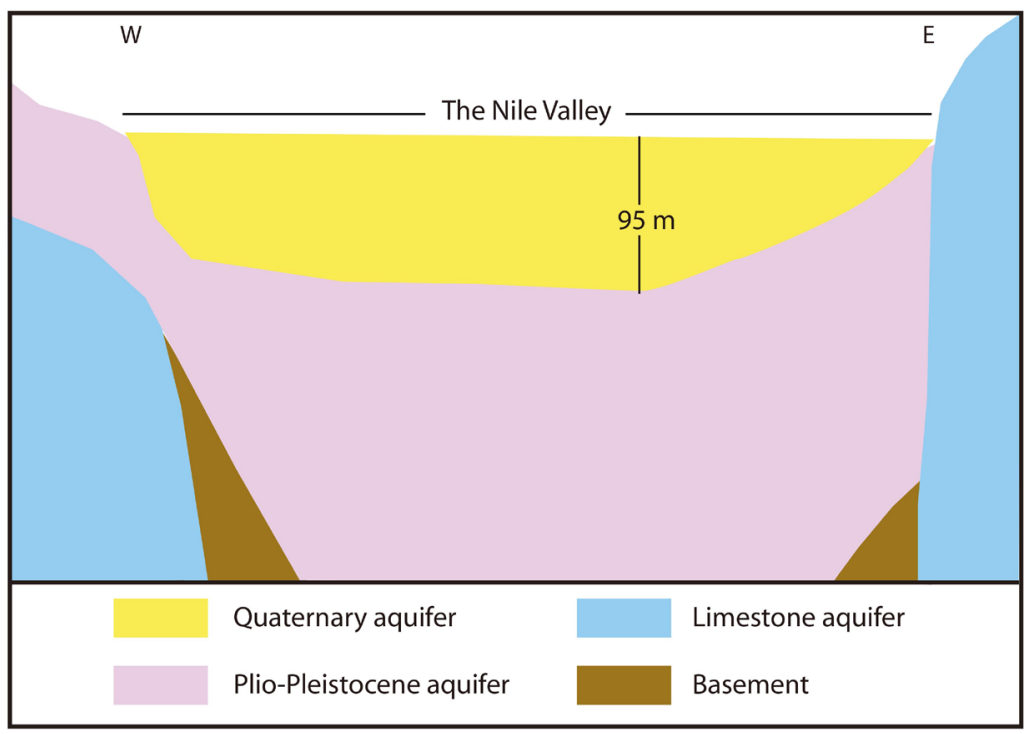

Figure 4. E-W hydrostratigraphic cross section across Maghagha area [30].

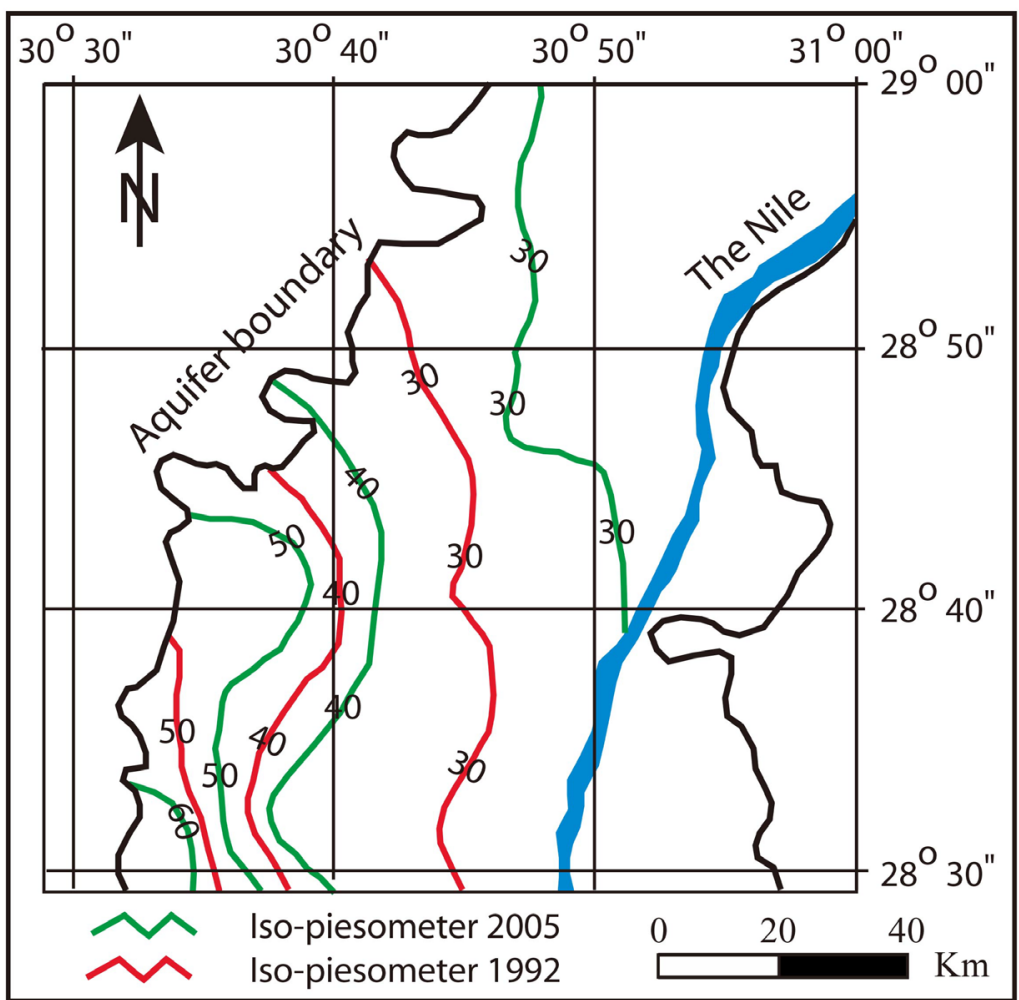

Figure 5. Potentiometric map in1992 (The hydrogeological map of Maghagha) and 2005 for the Quaternary aquifer in West Maghagha area.

thickness varies locally with an average thickness of $\sim 60 \mathrm{~m}$. The total groundwater abstraction from Plio-Pleistocene aquifer was estimated by RIGW/IWACO in [30] to be approximately $11 \times 10^{3} \mathrm{~m}^{3} /$ day with the large share dominantly consumed within the eastern fringes at Luxor. The Lower Eocene aquifer represents the main groundwater supply outside the Nile Valley and produces mainly 
from the calcareous units forming the eastern and western plateaux neighboring the Nile Valley. The land development projects for agriculture at the desert fringes on both sides of the Nile Valley depend basically on the Lower Eocene aquifer but the water quality could be significantly brackish compared to both Quaternary and Plio-Pleistocene aquifers. Recently, El Sayed in [31] evaluated the impact of geologic setting on the groundwater potential of the Eocene limestone aquifer near El Minia to the East of the Nile River using geoelectric methods. He developed two groundwater exploitation priority maps to the investigated area where El-Minia and Samalut Formation showed a great potential for groundwater exploitation. In the present study, the Lower Eocene aquifers to the West of the Nile Valley are evaluated using resistivity techniques and the available geological data.

\section{Methods}

The dominant subsurface hydrostratigraphic architecture of the study area is investigated using 17 VES of 600 to $800 \mathrm{~m}$ long within Schlumberger configuration. Despite the high-signal-to noise ratio, Schlumberger array provides a reasonable resolution in horizontal layers with adequate depth sensitivity [32]. In the present study, VESs are distributed to cover the different accessible parts in the study area and the acquired data are processed to reveal the subsurface architecture (Figure 2). The locations of the VESs are accurately surveyed using $\sim 410$ ground control points (GCPs), divided equally among the resistivity lines, using a handheld Garmin eTrex GPS unit with an expected horizontal accuracy less than $1 \mathrm{~m}$. Similarly, the coordinates of the midpoint at each VES-line are acquired while the ground level is determined using the available topographic map and the obtained value was subsequently checked for accuracy and consistency with Google Earth altitudes.

A successive increase in electrode separation with a series of measurements was applied to identify datum levels [33]. The measurements normally start with a unit spacing (typically 2, 3, 5, or $10 \mathrm{~m}$ ) in the first traverse and then increasing the electrode separation by adding a unit spacing to acquire a subsequent measurement. A detailed description of this field method is described by Abdulaziz in [34]. For each measurement, the potential difference $(\Delta V)$ between potential electrodes and the electric current intensity between the current electrodes are measured using a highly sensitive Voltmeter and micro-Ammeter respectively (Figure 1). To minimize the soil effect and maintain the contact resistance below or within $2 \mathrm{k} \Omega$, a saline solution is dispensed around the electrode. The power supply that normally secures 300 to 500 volt that sometimes approaches 800 volt in long profiles and insulated cables of armored copper are utilized during field work and data acquisition. The field measurements were carried out using Res-Master 8I61P Terrameter in a Schlumberger configuration that enabled depth of penetration of approximately $130-160 \mathrm{~m}$.

Interpretation of the obtained apparent resistivity data is accomplished using forward modeling and automatic inversion by IPI-2 win (2005) software [34]. 
Data processing of the VES typically starts with investigating all data set for consistency using log-log plot of the apparent resistivity $(\rho)$ versus $\mathrm{AB} / 2$ (Figure 6). This enables data smoothing through filtering false data points that unfit to the overall profile and attenuate resistivity variations at greater depths. A great caution is taken during this step to avoid replacing real field reading by false data points [35]. The resulting curve of each VES is compared to Orellana and Money master curves for layered structures [36]. This identifies geoelectric unit of known thickness $(\mathrm{m})$ with physical properties differs from the other units located above and below and interpretation results are constrained as possible using available geological data (Figure 6).

\section{Results and Discussion}

Normally, the resulting geoelectric sections don't coincide with the acknowledged stratigraphic column of the study area. Consequently, careful visual interpretation of the obtained geoelectric section and stratigraphic column of the study area is maintained in order to define the optimum match that acknowledges both datasets within the available ground truth. A hydrostratigraphic framework for modeled resistivity interpretation (Figure 7) is developed using

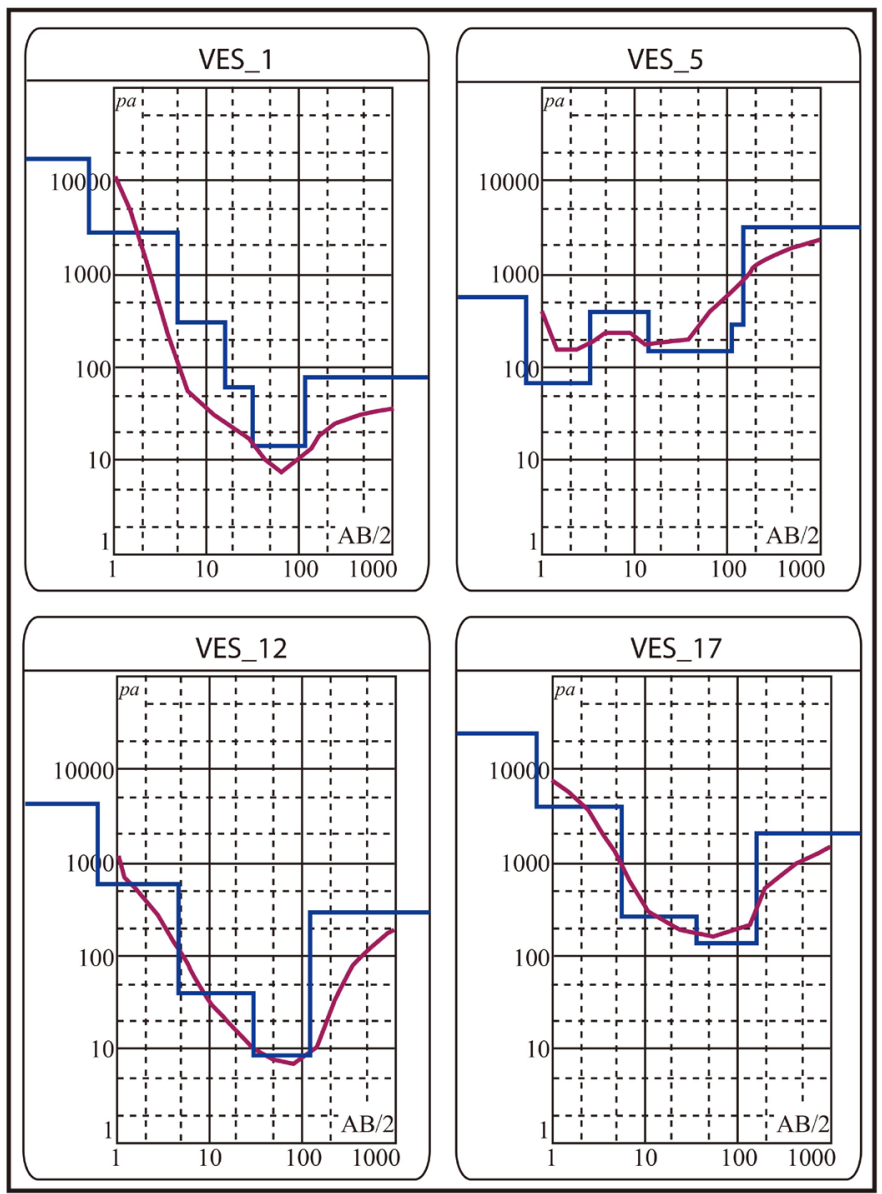

Figure 6. Samples of the interpreted curves of VES in West Maghagha area. 


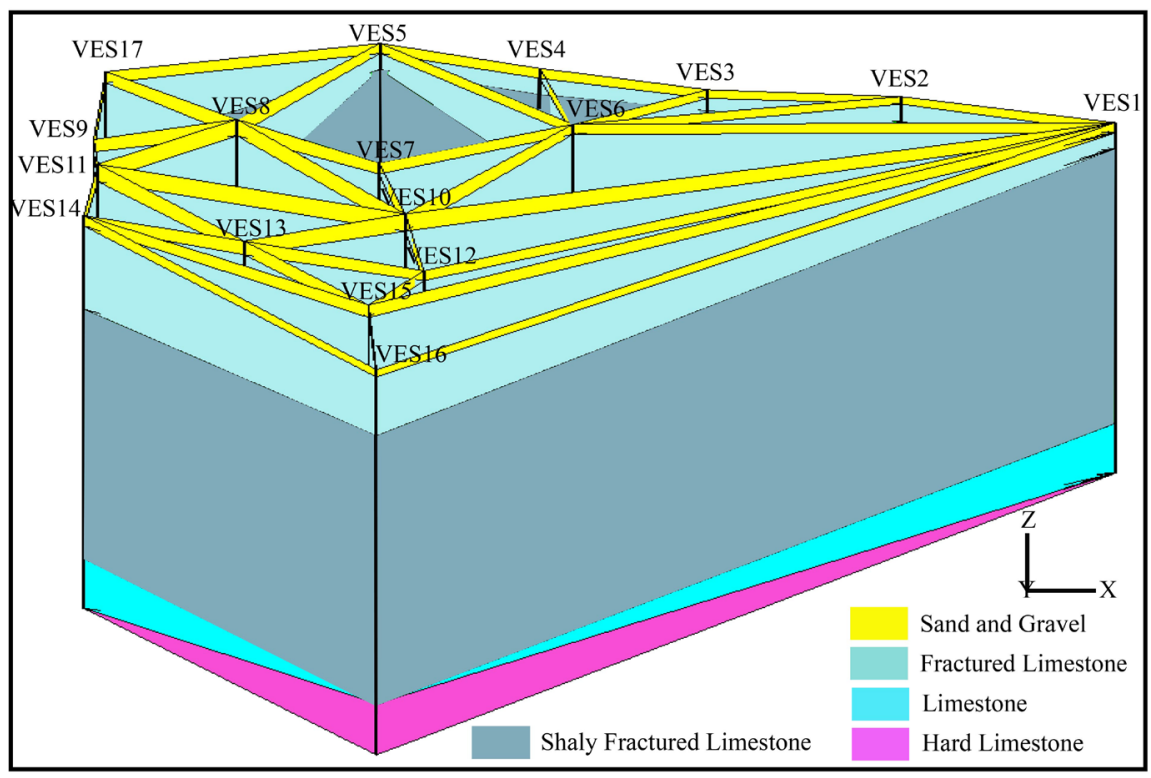

Figure 7. A hydrostratigraphic framework for the modeled VES in West Maghgha area.

available lithostratigraphic data of the study area and published literatures (e.g. [24] [31]). The final output of such interpretation involves 5 composite hydrostratigraphic/geoelectric sections that not only provides complete hydrostratigraphic units but also indicates their lateral extension within the recognized geologic structures (Figures 8-12). The model resistivity of each individual hydrostratigraphic units is presented in Table 1 and is used to identify the possible water-bearing horizons. In addition, a fault map (Figure 13) and aquifer thickness maps of Maghagha and Samalut Formation (Figure 14) are constructed from the interpreted VESs.

Generally, the layered structure of the indicated four hydrostratigraphic units with model resistivity between 6 and $4000 \mathrm{Ohm} \cdot \mathrm{m}$ and a fifth layer encountered in few VESs representing the massive unfractured limestone formulate the main penetrated geologic units (Figures 8-12). The first layer corresponds to alluvial sand and shale with significant variations in model resistivity that record as low as $15 \mathrm{Ohm} \cdot \mathrm{m}$ at clay section to over $3500 \mathrm{Ohm} \cdot \mathrm{m}$ where dry sand, gravel and/or probably boulders is encountered. The second layer involves a mixture of calcareous sediments and terrigenous intercalations and/or impurities with model resistivity around $300 \mathrm{Ohm} \cdot \mathrm{m}$ but may reach $950 \mathrm{Ohm} \cdot \mathrm{m}$ where few clay impurities and less fractures are developed. Alternatively, the model resistivity of the second layer may record less than $70 \mathrm{Ohm} \cdot \mathrm{m}$ where substantial clay intercalations exist but in all cases the hydrostratigraphic facies of the second layer closely correspond to that of Maghagha Formation. The third layer showed model resistivity between 2 and $130 \mathrm{Ohm} \cdot \mathrm{m}$ which mostly corresponds to saturatedfractured carbonates of Samalut Formation. This unit showed various shale content and constitutes the potential aquifer at the boundary of the Nile Valley with a relatively thick extending aquifer system. The fourth layer closely corresponds 


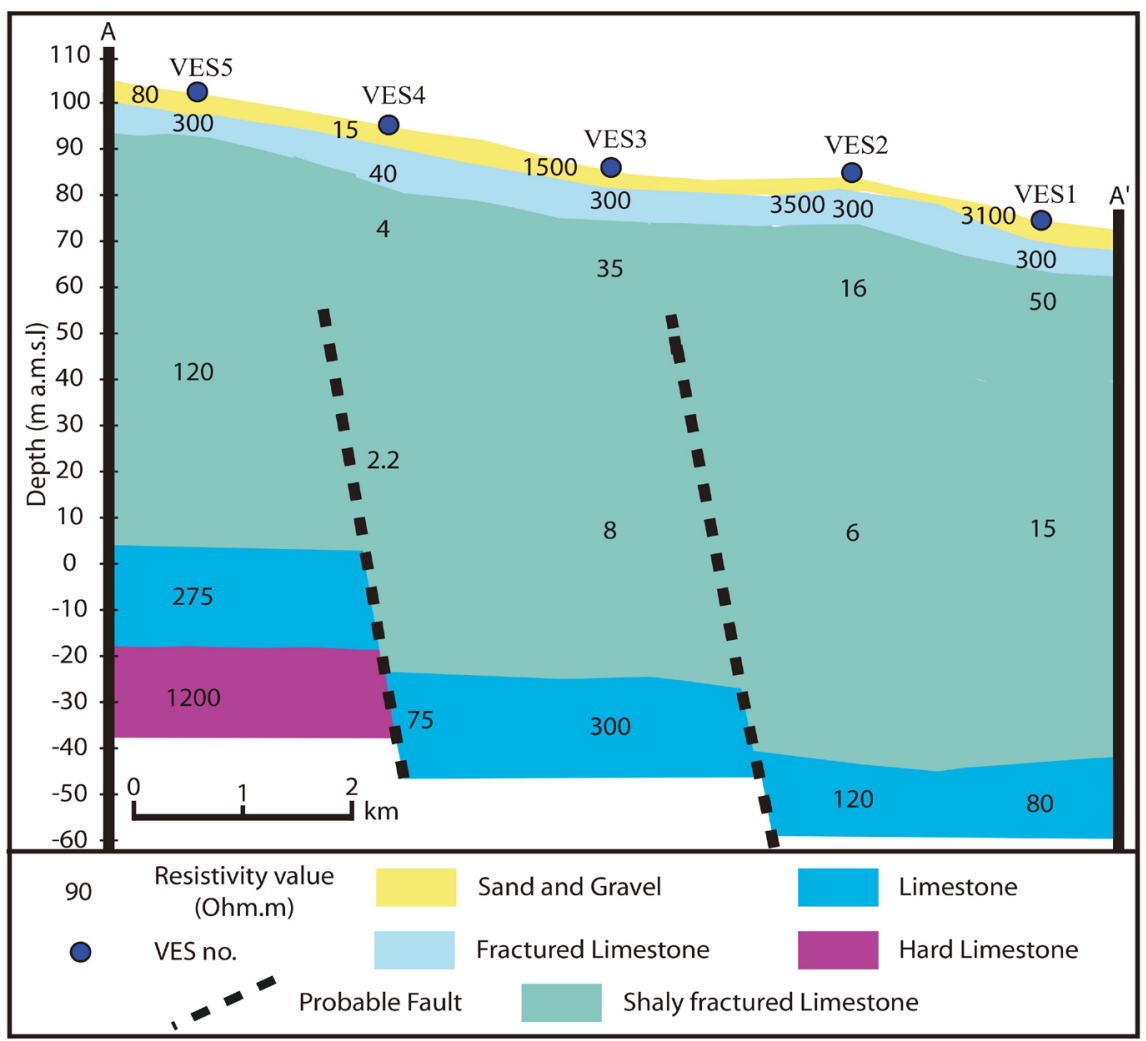

Figure 8. A composite geoelectric cross section along the $\mathrm{AA}^{-}$profile as interpreted from VESs 1 to 5 shown in Figure 2.

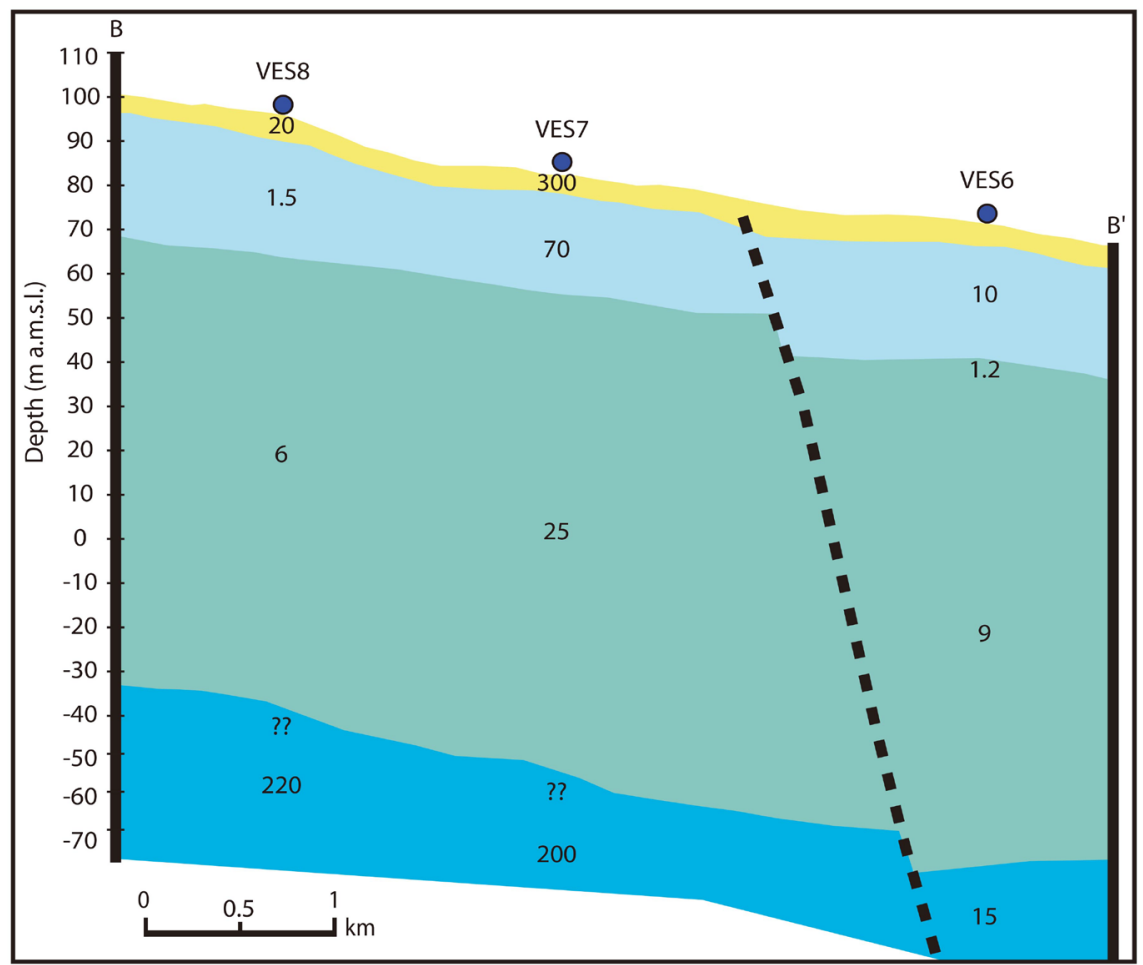

Figure 9. $\mathrm{BB}^{-}$Composite geoelectric section constructed using VESs 6 to 8 presented in Figure 2 and symbols as shown in Figure 8. 


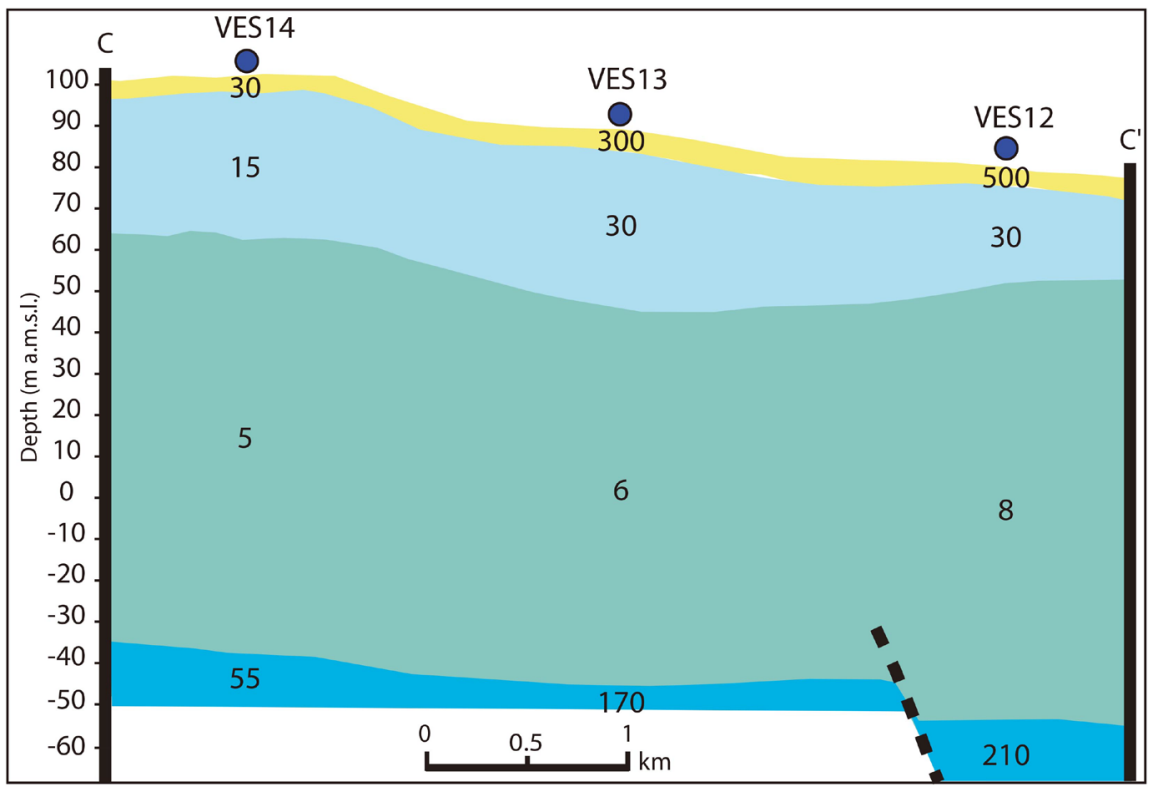

Figure 10. A Compiled geoelectric cross section along the $\mathrm{CC}^{-}$profile from VESs 12 to 14 presented in Figure 2 and symbols as shown in Figure 8.

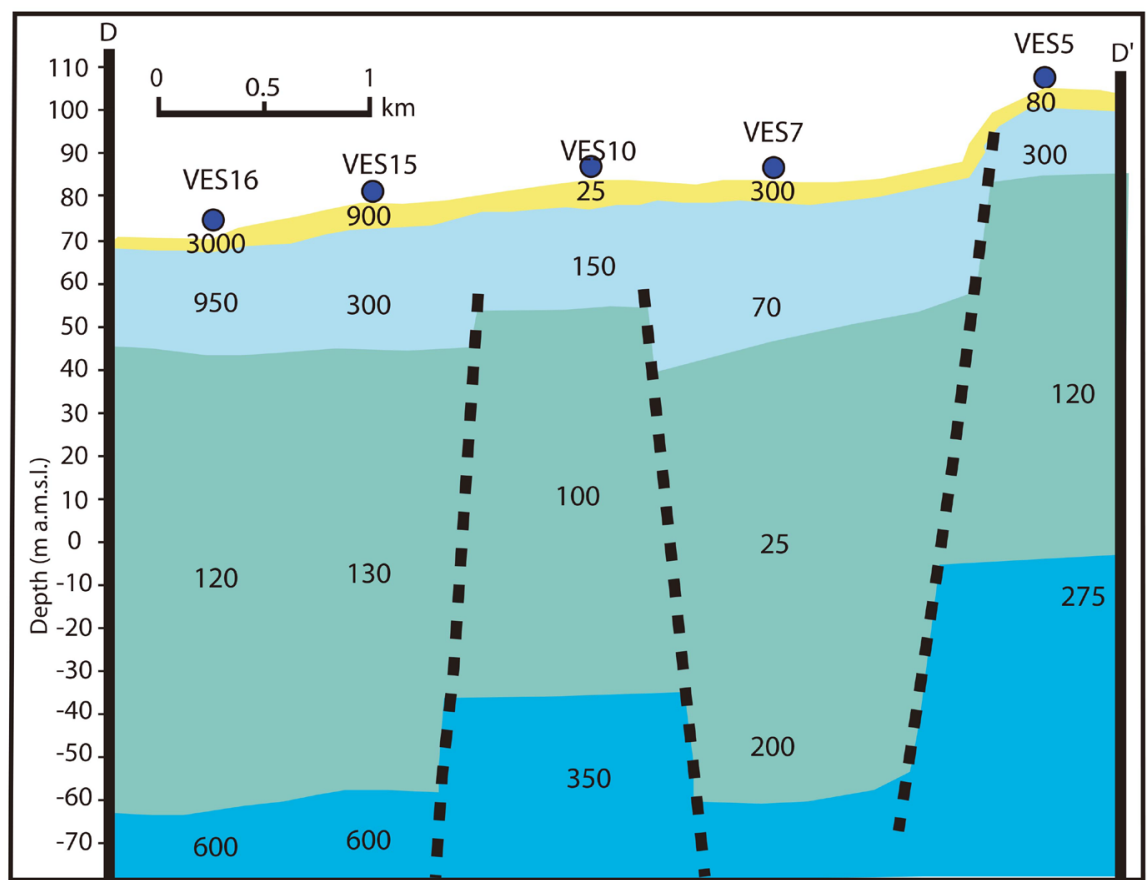

Figure 11. $\mathrm{DD}^{-}$Compiled geoelectric cross section from VESs 5, 7, 10, 15, and 16 displayed in Figure 2 and symbols as shown in Figure 8.

to the Minia Formation and consists of limestone with less developed fractures and average model resistivity between 250 to $350 \mathrm{Ohm} \cdot \mathrm{m}$ that may approach lower values $(\sim 10 \mathrm{Ohm} \cdot \mathrm{m})$ where clay impurities become significant. The lower boundary of the fourth layer is not detected in VESs except in VES5 and EE profile (Figure 12) where the fourth layer hydrostratigraphically changed to the fifth geoelectric unit of dense limestone with model resistivity $1200 \mathrm{Ohm} \cdot \mathrm{m}$. 


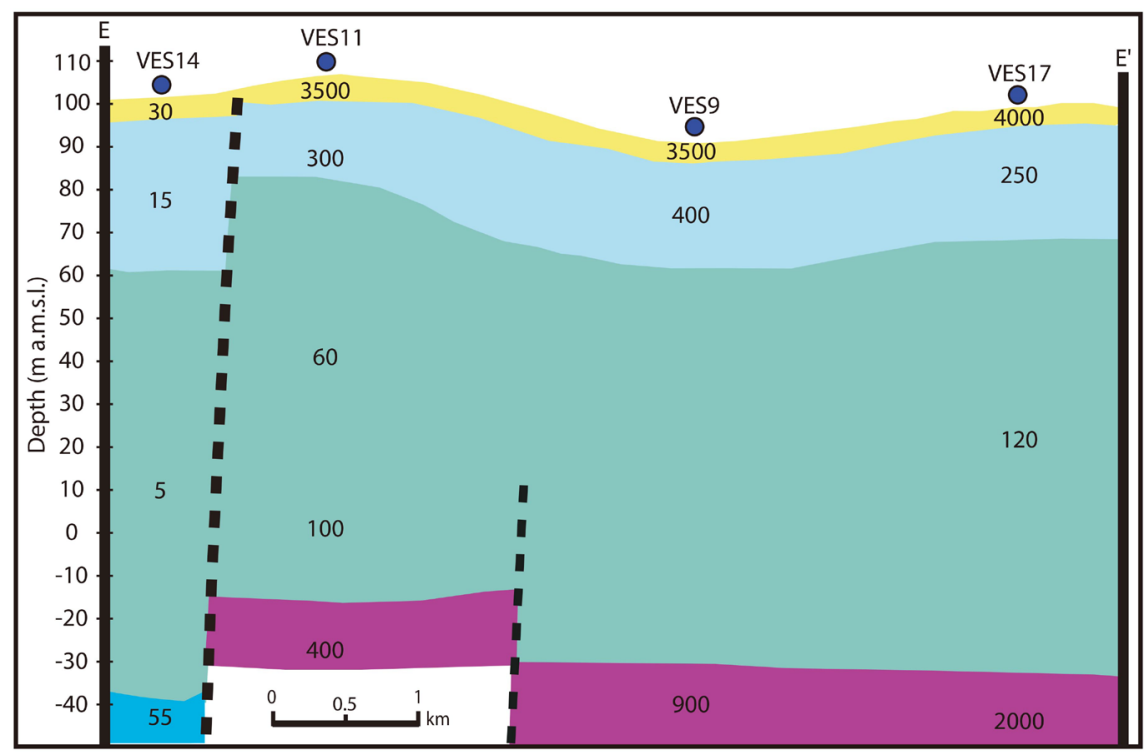

Figure 12. A Composite geoelectric section ( $\mathrm{EE}^{-}$) from VESs 9, 10, 14, and 17 shown in Figure 2 and symbols as shown in Figure 8.

Table 1. The model resistivity values calculated from 17 VESs for the successive geoelectric layers in West Maghagha area.

\begin{tabular}{cccccc}
\hline & Layer 1 & Layer 2 & Layer 3 & Layer $\mathbf{4}$ & Layer 5 \\
\hline VES1 & 3100 & 300 & 50 & $15 / 80$ & - \\
VES2 & 2500 & 300 & 16 & $6 / 120$ & - \\
VES3 & 1500 & 300 & 35 & $8 / 300$ & - \\
VES4 & 15 & 40 & 4 & $2.5 / 75$ & - \\
VES5 & 80 & 300 & 120 & 275 & 1200 \\
VES6 & 10 & 1.2 & 9 & 15 & - \\
VES7 & 300 & 70 & 25 & 200 & - \\
VES8 & 20 & 1.5 & 6 & 220 & - \\
VES9 & 3500 & 400 & 100 & - & 900 \\
VES10 & 25 & 150 & 100 & 350 & - \\
VES11 & 3500 & 300 & 60 & - & 400 \\
VES12 & 500 & 30 & 8 & 210 & - \\
VES13 & 300 & 30 & 6 & 170 & - \\
VES14 & 30 & 15 & 5 & 55 & - \\
VES15 & 900 & 300 & 130 & 600 & - \\
VES16 & 3000 & 950 & 120 & 600 & - \\
VES17 & 4000 & 250 & 120 & - & 2000 \\
\hline
\end{tabular}

Five VESs (VES1 to VES5) situated along the E-W direction (Figure 2) are utilized to construct $\mathrm{AA}^{-}$geoelectric cross section that enable penetration down to $140 \mathrm{~m}$ (Figure 8). The geoelectric cross section demonstrated a well-developed multi-layers section with 5 discrete geoelectric layers. The first (upper) geoelectric unit is composed of sandy gravel and sandy shale with average thickness $9 \mathrm{~m}$ and a relatively high resistivity $(\sim 3000 \mathrm{Ohm} \cdot \mathrm{m})$. This unit overlies a thick 


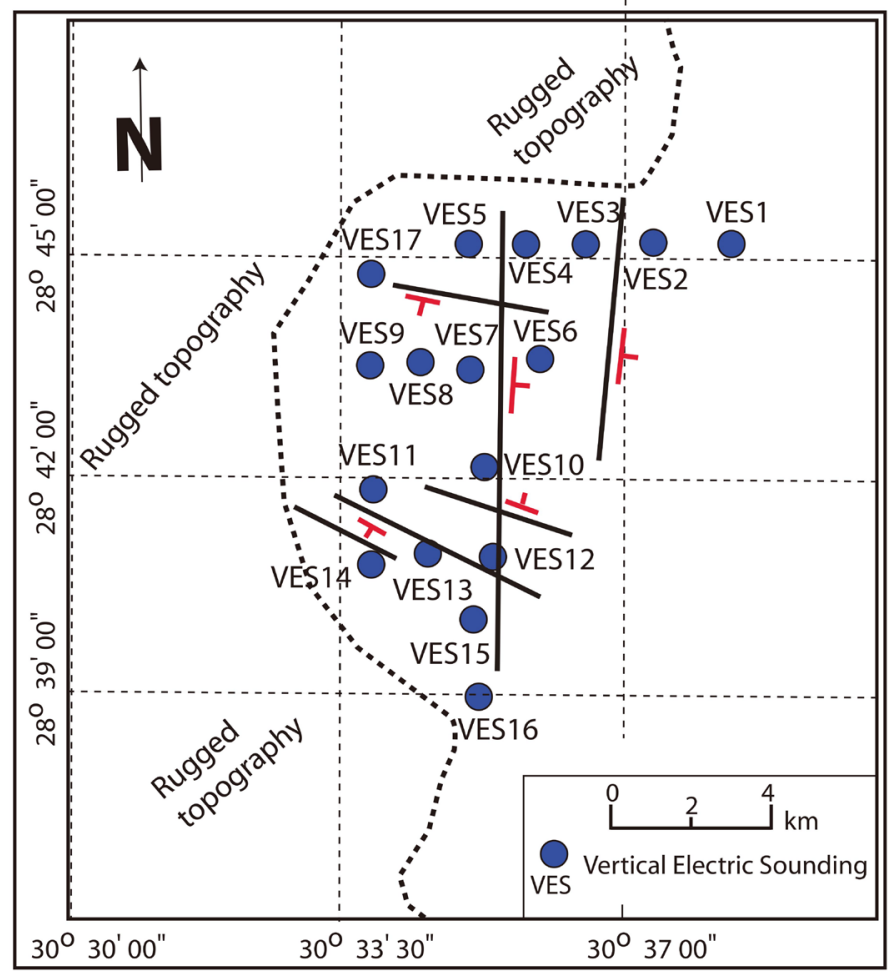

Figure 13. A fault map showing the inferred faults within West Maghagha area.
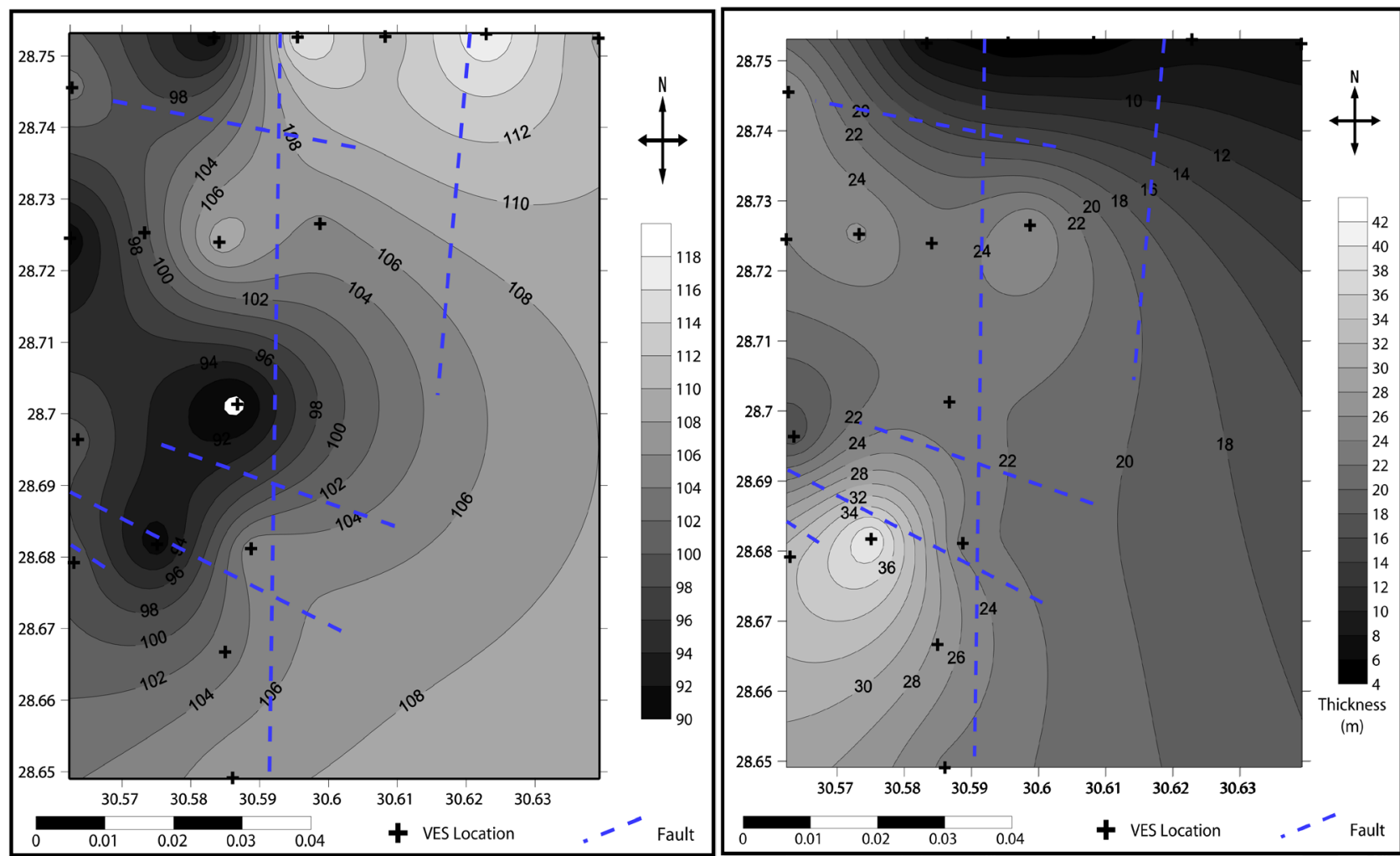

Figure 14. Aquifer thickness mapsof Maghagha Formation (Left) and Samalut Formation (Right) constructed from 17 VES, West Maghagha area. 
succession of calcareous sediments that vary strongly in the intensity of the developed fracture system, water saturation and shale impurities. The upper zone with the carbonate succession shows a well-developed fracture system but has minimal water saturation. Despite the dry nature of the upper carbonates zone, low model resistivity $(40 \mathrm{Ohm} \cdot \mathrm{m}$ ) is encountered at VES4 that can be related to excessive shale impurities or perched water conditions. Below this zone, a relatively low resistivity unit ( 2.2 to $120 \mathrm{Ohm} \cdot \mathrm{m})$ is approached at $12-15 \mathrm{~m}$ depthbelow ground surface. It shows a local variation in facies from east to west and downward increase in shale content (Figure 8). The lower part of this geoelectric section (Minia Formation) is occupied by two separate zones of moderately to highly resistive carbonate with the lower zone made dominantly of massive limestone overlained by slightly fractured zone. The slightly fractured limestone layer can be easily traced through the section but the massive limestone was only encountered in VES5. The resistivity of the massive limestone zone is generally above $1000 \mathrm{Ohm} \cdot \mathrm{m}$ while the slightly fractured carbonates are generally over 100 $\mathrm{Ohm} \cdot \mathrm{m}$ but shale impurities may significantly lower these value (Table 1 ).

Each of $\mathrm{BB}^{-}$and $\mathrm{CC}^{-}$geoelectric section (Figure 9 and Figure 10) is constructed using three VESs (VES6, VES7, and VES8 for $\mathrm{BB}^{-}$and VES12, VES13, and VES14 for $\mathrm{CC}^{-}$) and extend parallel to the $\mathrm{AA}^{-}$geoelectric section but located southward (Figure 2). The subsurface stratigraphic successions developed in $\mathrm{BB}^{-}$and $\mathrm{CC}^{-}$(Figure 9 and Figure 10) show geoelectric units closely similar to that imaged in $\mathrm{AA}^{-}$section (Figure 8) but with different unit thicknesses and the complete absence of the fifth resistive carbonate unit. The upper geoelectric unit seems match-able in thickness but the model resistivity measured in $\mathrm{BB}^{-}$ and $\mathrm{CC}^{-}$is notably lower. In contrast the second geoelectric unit seems to increase to the South with much lower model resistivity in $\mathrm{BB}^{-}$and $\mathrm{CC}^{-}$sections compared to that recorded in $\mathrm{AA}^{-}$section. The average thickness of the second unit reports 20 and $40 \mathrm{~m}$ in $\mathrm{BB}^{-}$and $\mathrm{CC}^{-}$sections respectively (Figure 9 and Figure 10) while the same layer did not approach $10 \mathrm{~m}$ thick in $\mathrm{AA}^{-}$section (Figure 8). The second geoelectric unit overlies argillaceous fractured carbonate aquifer (Samalut Formation) with a dominant model resistivity less than 10 $\mathrm{Ohm} \cdot \mathrm{m}$. The thickness of this aquifer increases northward from $90 \mathrm{~m}$ in $\mathrm{CC}^{-}$ section (Figure 10) to over $110 \mathrm{~m}$ in $\mathrm{AA}^{-}$section (Figure 8) with a relatively consistent model resistivity throughout this aquifer $(\sim 10 \mathrm{Ohm} \cdot \mathrm{m})$. The displacement of the normal fault was significantly perceptible in $\mathrm{BB}^{-}$section (Figure 9) but was barely seen in the lower part of $\mathrm{CC}^{-}$section (Figure 10) displacing the slightly fractured carbonate unit based underneath the argillaceous carbonate aquifer. This lower geoelectric unit showed various resistivity measurements that dominantly fall between 120 and $200 \mathrm{Ohm} \cdot \mathrm{m}$ but may reach 15 $\mathrm{Ohm} \cdot \mathrm{m}$ due to enhanced local water saturation and/or higher clay content (Figure 9 and Figure 10).

Both $\mathrm{DD}^{-}$and $\mathrm{EE}^{-}$geoelectric sections (Figure 11 and Figure 12) follow N-S direction with the VES5, VES7, VES10, VES15, and VES16 utilized to construct $\mathrm{DD}^{-}$and VES5, VES5, VES5, and VES5 used to prepare $\mathrm{EE}^{-}$section (Figure 2). 
Typically, a similar succession as shown in $\mathrm{AA}^{-}$to $\mathrm{CC}^{-}$is depicted in $\mathrm{DD}^{-}$and $\mathrm{EE}^{-}$sections but the $\mathrm{EE}^{-}$section (Figure 12) indicated that the massive/resistive carbonate geoelectric unit is encountered closer to the ground surface by the action of the normal fault located to the South. The aquifer thickness did not show a marked change in resistivity except where VES14 was recorded. This could be related to the effect of the fault gouge that could provide a permeable zone that enables significant groundwater accumulation and inconsequence distinctly influenced the resistivity recorded at VES14 (Figure 12). The hydrostratigraphic units developed within the study area are structurally affected by a number of normal faults (Figure 13) that develop a stepping pattern as presented in the eastern and southern parts of the study area or attain a horst structure as developed in the Midwest (Figure 13). Such faults definitely affect the continuity of the aquifer system and in consequence the occurrence and productivity of the aquifer are maintained maximum within the fault gouge and downthrown sections. Generally, the faults showed a relatively steep dip angle that typically fall between $70^{\circ}$ and $85^{\circ}$ in NNE direction. The $\mathrm{AA}^{-}$geoelectric section (Figure 3) confirms the occurrence of two important step faults following the dominant direction of the Nile at this locality (NNE-SSW) with a considerable downthrow, $10 \mathrm{~m}$ in the eastern fault and $23 \mathrm{~m}$ along the western fault. On the other hand, the $\mathrm{DD}^{-}$geoelectric section (Figure 11) showed a horst structure developed by two normal faults oriented EW, perpendicular to the Nile trajectory, and the dip slip across these faults falls between $2 \mathrm{~m}$ to $15 \mathrm{~m}$. Other important faults are depicted in $\mathrm{BB}^{-}, \mathrm{CC}^{-}$, and $\mathrm{DD}^{-}$(Figures 9-11 respectively) that typical exceeds $10 \mathrm{~m}$ in their dip slip and dominantly affect the lower parts of Samalut Formation and could be traced in Minia Formation as well. Generally, the developed structures are consistent with the tectonic activities and the resulting structures prevailed during the Miocene time.

The aquifer thickness maps (Figure 14) may indicate the aquifer potential to provide a groundwater supply for sustainable development. The shallow aquifer system (Maghagha Formation) showed a relatively average thickness of $20 \mathrm{~m}$ that typically increases towards the southwest and typically fall between $5 \mathrm{~m}$ as depicted in VES 7 and $40 \mathrm{~m}$ in VES 13 (Figure 14, Left). The deep aquifer system (Samalut Formation) represents the important water supply in the study area with a thickness falls between $90 \mathrm{~m}$ in VES 10 and $118 \mathrm{~m}$ in VES 2. The isochore map of the deep aquifer (Figure 14, Right) shows a moderate aquifer thickness towards the southeastern corner of the study area but local increase towards the northeast is also reported. Thus, the southern part of the investigated area has relatively a slight potential relative to the northern part, given that the water quality remains unchanged.

\section{Conclusion}

The integration of the present geoelectric study in West Maghagha area with the available geological and hydrogeological information allowed evaluating subsur- 
face architecture and the overall geologic conditions. Such information is critical and useful for delineating groundwater potential of the developed aquifers. Generally, a high resistivity zone $(\sim 1000 \mathrm{Ohm} \cdot \mathrm{m})$ can be recognized to delineate the massive carbonate unit encountered at $120 \mathrm{~m}$ below the ground surface (Minia Formation). This unit is generally overlained by a medium resistivity layer of Minia Formation (200 Ohm $\cdot \mathrm{m}$ ) as a transition zone to the potential aquifer. A second resistive layer is always found on the surface and usually consists of dry sand and gravel. The potential aquifer system developed in the study area involves the deep fractured limestone and shaly fractured limestone of Samalut Formation. The thickness $(\sim 90 \mathrm{~m})$ and extension of this aquifer are usually affected by normal faults that may increase the thickness up to $120 \mathrm{~m}$ or disturb the overall groundwater flow by fault throw and/or fault gauges. The shallow aquifer corresponds to Maghagha Formation and is probably replenished by infiltration of rainfall at the adjacent elevated topography during flash flood, while the deeper parts may receive the infiltrated water of return irrigation and/or Nile water through the well-developed fracture systems.

\section{Acknowledgements}

The authors very much appreciate the support and help provided by the coworkers and helpers during the field work and data acquisition.

\section{References}

[1] Abdulaziz, M.A., Hurtado Jr., J.M. and Al-Douri, R. (2009) Application of Multitemporal Landsat Data to Monitor Land Cover Changes in the Eastern Nile Delta Region, Egypt. International Journal of Remote Sensing, 11, 2977-2996. https://doi.org/10.1080/01431160802558675

[2] Sadek, H., Soliman, S. and Abdulhady, H. (1989) Correlation between Different Models of Resistivity Sounding Data to Discover New Fresh Water Fields in Elsadat City, Western Desert, Egypt. Proceedings of the 7 th International Mathematical Geophysics Seminar, Free University of Berlin, Germany, 8-11 February, 329-346.

[3] Abuelata, A. and Hassanein, A. (1990) Comparative Study of the Geoelectric Characteristics and Water Qualities in the Cairo-Suez and Cairo-Sokhna Roads, Eastern Desert, Egypt. Mansoura Science Bulletin, 17, 511-532.

[4] Abdulaziz, M.A. (2014) Hydrostratigraphic Characterization of Groundwater Systems in Khatatba Area Using Vertical Electrical Sounding and Well Log Data, SW Nile Delta, Egypt. International Journal of Advancement in Earth and Environmental Sciences, 2, 39-50.

[5] Ekinci, Y. and Demirci, A. (2008) A Damped Least-Squares Inversion Program for the Interpretation of Schlumberger Sounding Curves. Journal of Applied Sciences, 8, 4070-4078. https://doi.org/10.3923/jas.2008.4070.4078

[6] Singh, U., Tiwari, R. and Singh, S. (2010) Inversion of 2-D DC Resistivity Data Using Rapid Optimization and Minimal Complexity Neural Network. Nonlinear Processes in Geophysics, 17, 65-76. https://doi.org/10.5194/npg-17-65-2010

[7] Abdelwahab, H. (2013) Comparison of 2D and 3D Resistivity Imaging Methods in the Study of Shallow Subsurface Structures. Greener Journal of Physical Sciences, 3, 149-158. 
[8] Abdulaziz, M.A., Hurtado Jr., J.M. and Faid, A. (2012) Hydrogeological Characterization of Gold Valley: An Investigation of Precipitation Recharge in an Intermountain Basin in the Death Valley Region, California, USA. Hydrogeology Journal, 20, 701-718. https://doi.org/10.1007/s10040-012-0840-8

[9] Negri, S., Leucci, G. and Mazzone, F. (2008) High Resolution 3D ERT to Help GPR Data Interpretation for Researching Archaeological Items in a Geologically Complex Subsurface. Journal of Applied Geophysics, 65, 111-120. https://doi.org/10.1016/j.jappgeo.2008.06.004

[10] Sabet, M. (1975) Vertical Electrical Resistivity Soundings to Locate Ground Water Resources: A Feasibility Study. A Publication of Virginia Water Resources Research Center Virginia Polytechnic Institute and State University Blacksburg, Bulletin, 73, Virginia, November 1975.

[11] Krumbein, W. and Sloss, L. (1963) Stratigraphy and Sedimentation. W.H. Freeman and Co., San Francisco, 660 p.

[12] Zohdy, A., Eaton, G. and Mabey, D. (1974) Application of Surface Geophysics to Ground-Water Investigations. U.S. Geological Survey Water-Resources Investigations, Book 2, United States Government Printing Office, U.S. Geological Survey, Denver, Co., 86.

[13] Yungel, S.H. (1996) Electrical Methods in Geophysical Exploration of Deep Sedimentary Basins. Chapman \& HaIl, London, $208 \mathrm{p}$.

[14] Parasnis, D.S. (1997) Principles of Applied Geophysics. 5th Edition, Chapman \& Hill, London, 429 p.

[15] Mait, S., Gupta, G., Erram, V. and Tiwari, R. (2011) Inversion of Schlumberger Resistivity Sounding Data from the Critically Dynamic Koyna Region using the Hybrid Monte Carlo-Based Neural Network Approach. Nonlinear Processes in Geophysics, 18: 179-192. https://doi.org/10.5194/npg-18-179-2011

[16] Said, R. (1981) The Geological Evolution of the River Nile. Springer Verlag, 151 p. https://doi.org/10.1007/978-1-4612-5841-4

[17] Mansour, H.H. and Pltilobbo, L.R. (1983) Lithostratigraphic Classification of the Surface Eocene Carbonate of the Nile Valley, Egypt: A Review. Faculty of Science, Assiut University, 12, 129-153.

[18] E.G.P.C. and CONOCO Coral Company (1987) Geological Map of Egypt, Scale 1: 500,000 Cairo, Egypt.

[19] Said, R., Wendorf, F. and Schild, R. (1970) The Geology and Prehistory of the Nile Valley in Upper Egypt. Archeologia, Polona, 12, 43-60.

[20] Said, R. (1990) The Geology of Egypt. Balkema, 734 p.

[21] Said, R. (1993) The River Nile Geology, Hydrology, and Utilization. Pergamon Press, Oxford, $320 \mathrm{p}$.

[22] Boukhary, M. and Abdelmalik, W. (1983) Revision of the Stratigraphy of the Eocene Deposits of Egypt. Neues Jahrbuch für Geologie und Paläontologie, 6, 321-337.

[23] Bishay, Y. (1961) Biostratigraphic Study of the Eocene in the Eastern Desert between Samalut and Assiut by the Larger Foraminifera. Third Arab Petrol. Cong., Alexandria, $7 \mathrm{p}$.

[24] Issawi, B., Francis, M.H., Yousef, E.A. and Osman, R.A. (2009) The Phanerozoic Geology of Egypt: A Geodynamic Approach. The Egyptian Geological Survey Special Publication No. 81, Ministry of Petroleum, the Egyptian Mineral Resources Authority, Abbaseya.

[25] Omara, S., El Tahiawi, M.R. and Hafez, H.H. (1970) The Geology of Environs of 
Assiut. Bulgarian Geographic Society, Vol. 43, Cairo.

[26] Yehia, M.A. (1973) Some Aspects of the Structural Geology and Stratigraphy of Selected Ports of the Nile Basin of Upper Egypt. PhD Thesis, Fac. Sci, Am Shams Univ., Egypt, 180 p.

[27] RIGW/IWACO (1990) Groundwater Potential in the Nile Valley and Delta. Technical Note 70.130-89-07.

[28] RIGW/IWACO (1988) Development and Management of Groundwater Resources in Nile Valley and Delta. Technical Note 70, 120-88-05, Cairo.

[29] RIGW/IWACO (1990b) Hydrogeological Inventory and Groundwater Development Plan-Western Nile Delta Region, Volume 1. Main Report TN 70.130-90-02, RIGW, Egypt.

[30] RIGW/IWACO (1991) Development and Management of Groundwater Resources in the Nile Valley and Delta. Internal Report, Cairo, Egypt.

[31] El Sayed, A.N. (2016) The Impact of Geologic Setting on the Groundwater Occurrence in the Eocene Limestone of El Minia-East Nile-Egypt using Geoelectrical Technique. Advances in Applied Science Research, 7, 257-273.

[32] Ward, S. (1990) Resistivity and Induced Polarization Methods, In: Ward, S.H., Ed., Geotechnical and Environmental Geophysics, Vol. 1, Society of Exploration Geophysicists, Tulsa. https://doi.org/10.1190/1.9781560802785

[33] Barseem, M., El Sayed, A. and Youssef, A. (2013) Impact of Geologic Setting on the Groundwater Occurrence in Wadis El Sanab, Hashem, and Khrega using Geoelectrical Methods-Northwestern Coast, Egypt. Arabian Journal of Geoscience, 7, 5127-5139. https://doi.org/10.1007/s12517-013-1129-5

[34] IPI-2win Software (2005) A Package for Automatic and Interactive Semiautomatic Interpretation of VES and IP Data. Moscow State University, Dep. of Geophysics and Geoscan, M. Ltd.

[35] Mack, T. and Degnan, J. (2004) Geophysical Characterization of Fractured Bedrock at Site 8, Former Pease Air Force Base, Newington, New Hampshire. USGS OpenFile Report 02-279.

[36] Orellana, E. and Money, H. (1966) Master Tables and Curves for Vertical Electrical Sounding over Layered Structures. Interciencia, Costanilla de Los Angeles, 15, Madrid. 